\title{
Return Saham, Faktor Fundamental, Dan Resiko Sistematis Pada Perusahaan Konstruksi Dan Infrastruktur Yang Terdaftar Di Bursa Efek Indonesia Tahun 2015-2019
}

\author{
Muhammad Adnan Azzaki \\ Universitas Islam Negeri Sunan Kalijaga Yogyakarta \\ 19208010039@student.uin-suka.ac.id
}

\section{Slamet Haryono}

Universitas Negeri Sunan Kalijaga Yogyakarta

slamet.haryono@uin-suka.ac.id

\begin{abstract}
Abstrak
Perusahaan Konstruksi dan Infrastruktur merupakan perusahaan yang memiliki potensi besar dalam menghasilkan return/keuntungan. Hal ini dikarenakan sektor konstruksi dan infrastruktur menjadi prioritas pembangunan di banyak negara terkhusus di Indonesia. Penelitian ini bertujuan untuk menganalisis pengaruh faktor Fundamental dan Resiko sistematis perusahaan Konstruksi dan Infrastruktur yang berada di bursa efek indonesia terhadap return saham pada tahun 2015-2019. Menggunakan data sekunder dengan alat analisis regresi panel, maka dapat disimpulkan bahwa dari hasil uji $\mathrm{t}$ statistik melalui pendekatan secara parsial, variabel Rasio Profitabilitas, Rasio pasar, dan Resiko sistematis berpengaruh secara signifikan terhadap return saham. Sedangkan variabel Rasio likuiditas dan Rasio solvabilitas tidak memiliki pengaruh signifikan terhadap return saham. Adapun hasil uji F statistik dapat disimpulkan bahwa secara simultan faktor fundamental yaitu Rasio Profitabilitas, Rasio likuiditas, Rasio solvabilitas, Rasio pasar, dan Resiko sistematis berpengaruh signifikan terhadap return saham pada perusahaan konstruksi dan infrastruktur di bursa efek indonesia pada tahun 20152019. Hasil penelitian ini dapat menjadi tambahan literatur baru terutama bagi investor dalam menganalisis kondisi perusahaan yang berada pada sektor Konstruksi dan Infrastruktur, dalam memperoleh return/keuntungan di pasar modal.
\end{abstract}

Kata Kunci Return Saham, Faktor Fundamental, Resiko Sistematis

\section{PENDAHULUAN}

Saat ini saham perusahaan konstruksi dan Infrastruktur telah menarik perhatian para investor. Hal ini disebabkan kebutuhan permintaan pembangunan gedung, jalan maupun fasilitas publik terjadi peningkatan yang cukup pesat, dan menjadi skala prioritas banyak pemerintahan di dunia pada sektor konstruksi dan infrastruktur ini. Permintaan dan kebutuhan yang meningkat tersebut menyebabkan penambahan kontrak proyek baru, sehingga hal ini berpotensi menyebabkan terjadinya peningkatan keuntungan bagi perusahaan di sektor konstruksi dan infrastruktur. Peningkatan keuntungan ini akan berbanding lurus dengan kenaikan harga saham. Investor menjadikan hal tersebut sebagai peluang yang menarik dalam membeli saham perusahaan konstruksi dan Infrastruktur (Pheng dan Hou, 2019). 
Investor memiliki tujuan melakukan investasi baik dalam bentuk apa pun adalah melihat suatu peluang yang memiliki potensi pengembalian/return terhadap investasi yang sudah ditanam. Pasar modal memiliki keuntungan/return yang diharapkan yaitu berupa dividen dari perusahaan yang menerbitkan saham (emiten) atau dapat berasal dari selisih positif antara harga saham yang dibeli dengan harga pada saat dijual atau yang disebut capital gain (Mustofia et al., 2019).

Investor memiliki strategi dalam memperoleh return atau keuntungan yaitu dengan mempertimbangkan melakukan investasi di sektor Konstruksi dan infrastruktur. Sektor ini memiliki kebijakan terkait dengan keuntungan bagi investor berupa dividen yang terdiri dari dividen payout ratio dan dividen yield (Hooi et al., 2015). Kebijakan ini merupakan kebijakan manajerial yang dilihat dari berapa banyak laba bersih yang dibayarkan sebagai dividen kepada investor dan berapa banyak laba bersih yang dipertahankan bagi perusahaan (Marinda, 2017).

Investor yang berpikir secara rasional akan melakukan analisis faktor yang dapat berpengaruh terhadap return saham. Analisis tersebut terdiri dari analisis teknikal dan analisis fundamental. Analisis teknikal memerlukan data historis berupa volume penjualan dan harga saham. Analisis fundamental memiliki tujuan untuk mengetahui nilai intrinsik suatu saham, analisis fundamental meliputi analisis ekonomi, analisis industri, dan analisis perusahaan (Yasmeen, 2015).

Faktor fundamental terhadap return saham pada sektor konstruksi dan infrastruktur masih perlu diteliti terutama pada saat mengalami tren bullish. Analisis tersebut sangat penting, sebagai bahan pertimbangan bagi investor sebelum mengambil keputusan investasi yang mana kondisi bullish tersebut menjadikan pasar sudah overbought, karena harga aset perusahaan sudah mengalami overvaluasi sehingga rentan terhadap koreksi fundamental maupun teknikal pada masa yang akan datang (Čaljkušić, 2011).

Theodore Goodman, et al (2018) menjelaskan bahwa pentingnya memberikan informasi data akuntansi tentang arus kas yang diharapkan suatu perusahaan di masa depan, dalam hal ini investor menerima informasi dari manajemen perusahaan. Analisis data fundamental memiliki fokus terhadap pelaku pasar agar dapat menggunakan informasi akuntansi, sehingga mampu mengevaluasi volatilitas operasi perusahaan dan mengetahui harga arus pasar opsi secara akurat.

Penelitian (Thampanya. et al, 2020) dengan judul faktor Fundamental dan perilaku penentu volatilitas pengembalian saham di 5 negara ASEAN, hasil penelitian menyimpulkan bahwa faktor fundamental memainkan peran penting dalam mempengaruhi volatilitas pasar saham di Malaysia, Thailand, dan Singapura. Faktor perilaku mempengaruhi volatilitas pasar saham lebih signifikan dari pada faktor fundamental di Indonesia dan Filipina.

Investor jika ingin mendapatkan keuntungan/return dari selisih harga beli dengan harga jual, maka perlu memperhatikan volatilitas dari harga saham tersebut. Apabila terjadi volatilitas harian harga saham yang cukup tinggi, maka kemungkinan harga saham tersebut akan mengalami kenaikan dan penurunan harga saham yang cukup tinggi pula, hal ini dapat memberikan ruang untuk melakukan perdagangan dan transaksi demi mendapatkan keuntungan dari adanya perbedaan (margin) dari harga awal dengan harga akhir pada saat dilakukan transaksi, namun resiko yang dimiliki juga sangat besar. (Girard et al, 2009).

Volatilitas saham yang semakin tinggi, menyebabkan kepastian return suatu saham semakin rendah. Volatilitas yang tinggi memberikan potensi keuntungan yang 
tinggi. Volatilitas yang rendah menandakan adanya kestabilan dari nilai return saham, akan tetapi keuntungan yang didapatkan tidak terlalu tinggi. Perusahaan yang memiliki pola volatilitas saham yang rendah menunjukkan perusahaan tersebut berkualitas baik (Walkshäusl, 2013).

Investor juga harus mempertimbangkan risiko yang berkaitan dengan kepemilikan suatu saham. Investasi pada saham mempunyai tingkat risiko yang lebih besar dibandingkan dengan investasi lainnya seperti obligasi, deposito dan tabungan. Investasi di saham memiliki ketidakpastian yang cukup tinggi, sehingga perlu diketahui mengenai resiko yang dapat di analisis. Teori portofolio modern memiliki jenis risiko yang terdapat pada suatu saham, yaitu risiko sistematis dan risiko yang tidak sistematis (Stölzle, 2011).

Risiko yang menjadi perhatian para investor adalah risiko sistematis, karena resiko ini dapat di analisa maupun di kalkulasi menggunakan info dan teknik yang relevan. Resiko sistematis yaitu risiko yang disebabkan oleh kondisi pasar dan perekonomian secara keseluruhan. Resiko sistematis disebabkan antara lain pengaruh nilai kurs valuta asing, tingkat suku bunga, kondisi politik dan lain-lain. Resiko sistematis memiliki ukuran yang disebut dengan (beta). Beta merupakan suatu koefisien yang menunjukkan kepekaan tingkat keuntungan suatu saham terhadap perubahan tingkat keuntungan indeks pasar saham (Campbell et al, 2010).

Peningkatan dan penurunan serta volatilitas harga saham dapat dinilai dengan melakukan pengujian pengaruh faktor fundamental yang terdiri dari rasio profitabilitas (Return on Asset), rasio solvabilitas (Debt to Equity Ratio), rasio likuiditas (Current ratio), rasio pasar (Price Earning Ratio), dan risiko sistematis (Beta) terhadap Return saham (Komala, 2013).

Beberapa hasil penelitian yang relevan terdapat beberapa perbedaan variabel maupun hasil analisis, sehingga perlunya melakukan penelitian lebih lanjut mengenai pengaruh faktor fundamental dan risiko sistematis terhadap return saham. Penelitian Rowland (2008) menemukan faktor fundamental yang diproksikan dengan DER memiliki pengaruh negatif secara langsung terhadap return saham. Penelitian Kilic, et al dalam Albed (2016) menyatakan bahwa faktor fundamental yang terdiri dari ROA secara signifikan berpengaruh positif terhadap return saham.

Sharpe, et al dalam Kusneri (2012) menyatakan bahwa hubungan antara risiko dan return yang diharapkan investor bersifat positif dan linear. Penelitian Coles, et al (2004), Solechan (2010) menyatakan risiko sistematis (Beta) tidak memiliki pengaruh terhadap return saham.

Penelitian ini tidak memasukkan pengujian terhadap variabel makro ekonomi terhadap return saham. Penelitian (Yang, 2019) menyatakan bahwa sebenarnya pasar saham bersifat antisipatif terhadap kondisi perekonomian, dengan kata lain kondisi pasar merefleksikan kondisi ekonomi, maka setiap perubahan kondisi ekonomi tentunya akan tercermin pada kondisi pasar. Kondisi pasar saat ini mencerminkan harapan para pemodal terhadap kondisi ekonomi di masa yang akan datang.

Perusahaan Konstruksi dan Infrastruktur diambil sebagai sampel penelitian karena perusahaan ini memiliki potensi besar dalam menghasilkan return/keuntungan. Sektor konstruksi dan infrastruktur menjadi prioritas pembangunan di banyak negara terkhusus di Indonesia, sehingga layak diteliti mengenai kondisi fundamental maupun tantangan berupa resiko yang dimiliki oleh perusahaan Kostruksi dan Infrastruktur. Penelitian ini bertujuan untuk menganalisis pengaruh faktor Fundamental dan Resiko 
sistematis perusahaan Konstruksi dan Infrastruktur yang berada di bursa efek indonesia terhadap return saham pada tahun 2015-2019.

\section{LANDASAN TEORI \\ 1. Return Saham}

Return saham adalah keuntungan yang diperoleh dari kegiatan investasi di pasar modal. Return saham berupa tingkat keuntungan yang di dapatkan oleh investor atas suatu investasi yang dilakukan. Keuntungan atau return saham yang di peroleh Investor berupa dividen dan capital gain/loss (Rapach, 2013).

Dividen merupakan return yang diterima oleh pemegang aset dalam bentuk kas saham. Capital gain/loss adalah perubahan harga akibat terjadinya mekanisme pasar. Bagian ini terjadi karena terdapat perbedaan antara harga saham pada waktu beli (beginning price) dan harga saham pada waktu jual (ending price). (Jones, 1994).

Karakteristik investor sesuai dengan Bird In Hand Theory yaitu Investor lebih memilih uang tunai di tangan dalam bentuk dividen daripada mekanisme yang terjadi pada capital gain. Dividen lebih memberikan kepastian dalam keuntungan bagi investor, dibandingkan dengan capital gain yang lebih bersifat spekulatif (Hooi et al., 2015).

\section{Faktor Fundamental Perusahaan}

Rasio profitabilitas (ROA) adalah kemampuan perusahaan dalam menghasilkan laba yang berasal dari aset perusahaan (Ross et al., 2013). Nilai ROA yang tinggi, memiliki kecendrungan dalam menghasilkan laba yang tinggi. Investor akan lebih tertarik melakukan investasi pada perusahaan tersebut.

Rasio solvabilitas (DER) adalah rasio yang digunakan dalam mengukur tingkat utang yang digunakan melalui modal yang dimiliki perusahaan. DER memiliki pengaruh terhadap kinerja perusahaan, yaitu semakin tinggi nilai DER, maka semakin rendah pendanaan yang disediakan oleh pemegang saham (Kamar, 2017).

Perusahaan yang memiliki nilai DER yang terlalu tinggi, akan berdampak buruk terhadap kinerja perusahaan, hal ini mengindikasikan bahwa perusahaan memiliki tingkat utang yang tinggi dan beban bunga yang besar, sehingga menyebabkan penurunan laba pada perusahaan. Perusahaan ini dapat mengurangi kepercayaan investor, sehingga Investor cenderung menghindari saham yang memiliki Debt to Equity Ratio (DER) yang tinggi (Horne dan Wachowicz, 2008)

Rasio likuiditas (CR) merupakan suatu cara untuk menguji tingkat proteksi yang di peroleh pemberi pinjaman dalam bentuk kredit jangka pendek, yang diberikan kepada perusahaan untuk mendanai kegiatan operasional perusahaan. Nilai CR yang rendah pada suatu perusahaan dianggap memiliki masalah dalam likuiditas, sebaliknya nilai CR yang terlalu tinggi juga dianggap kurang bagus, karena hal tersebut mengindikasikan bahwa banyak dana perusahaan yang tidak di kelola, sehingga pada akhirnya dapat mengurangi kemampuan perusahaan dalam menghasilkan laba yang optimum (Madushanka, 2018). Investor akan memperoleh return yang lebih rendah jika kemampuan perusahaan memenuhi kewajiban jangka pendek semakin rendah.

Rasio pasar (PER) digunakan oleh para investor untuk memprediksi kemampuan perusahaan dalam menghasilkan laba dimasa depan. Investor dapat mempertimbangkan PER untuk memprediksi saham mana yang nantinya dapat memberikan keuntungan yang besar dimasa depan. Perusahaan dengan peluang tingkat pertumbuhan yang tinggi biasanya mempunyai PER yang tinggi, demikian pula sebaliknya perusahaan dengan 
pertumbuhan yang rendah memiliki PER yang kecil atau rendah. Perusahaan yang tidak memiliki laba maka kemungkinan nilai PER terlalu tinggi (Ross et al., 2013).

\section{Resiko sitematis $(\beta)$}

Risiko sistematis merupakan faktor ketidakpastian yang tidak dapat ditoleransi oleh setiap perusahaan, karena faktor-faktor penyebabnya dapat memengaruhi kondisi perusahaan secara keseluruhan. Faktor-faktor yang termasuk dalam risiko sistematis antara lain inflasi, suku bunga, kebijakan moneter, dan lainnya (Griffin, 2013).

Risiko sangat erat kaitannya dengan return. Resiko dan return tidak dapat dipisahkan karena semakin tinggi risiko yang akan ditanggung oleh investor maka akan semakin tinggi pula return yang didapatkan. Risiko sistematis diproksikan dengan koefisien beta $(\beta)$. Koefisien beta $(\beta)$ dikatakan netral apabila bernilai satu $(\beta=1)$, semakin besar nilai beta, maka semakin besar risiko dari saham tersebut, dan akan semakin tinggi pula return yang akan diterima (Hollstein, 2016).

\section{Pengaruh Faktor Fundamental Terhadap Return Saham}

Analisis rasio profitabilitas (ROA) dapat dijadikan penentu utama dari return saham melalui kebijakan dividen perusahaan. Perusahaan memilih untuk membayar dividen lebih ketika profitabilitas tinggi. Penelitian Al-Malkawi et al. (2013) menyatakan bahwa tingkat profitabilitas berpengaruh terhadap return saham berupa dividend yield. Saham perusahaan konstruksi berbeda dari saham biasa karena sifat perusahaan konstruksi yang heterogen dan volatilitas yang melekat. Berdasarkan penjelasan diatas maka hipotesis yang didapat sebagai berikut:

$\mathrm{H}_{1}$ : Return on asset (ROA) berpengaruh positif terhadap return saham

Menurut Al-Malkawi et al. (2013) bahwa perusahaan dengan leverage keuangan yang tinggi cenderung memiliki return yang rendah untuk mengurangi biaya transaksi terkait dengan pembiayaan eksternal. Perusahaan yang menggunakan pembiayaan dengan utang memiliki beban keuangan yang diwujudkan dalam pembayaran bunga dan pokok utang, dan kegagalan untuk memenuhi kewajiban tersebut dapat menyebabkan perusahaan dilikuidasi.

Risiko yang terkait dengan derajat utang tinggi dapat mengakibatkan pembayaran dividen rendah. Hal ini menyebabkan perusahaan perlu untuk mempertahankan arus kas internal untuk membayar kewajiban daripada mendistribusikan uang tunai kepada pemegang saham (Abor dan Bokpin, 2010). Berdasarkan penjelasan diatas maka hipotesis yang didapat sebagai berikut:

$\mathrm{H}_{2}$ : Debt equity ratio (DER) berpengaruh negatif terhadap return saham

Investor sering menghitung jumlah besar dengan berbagai cara dalam berbagai kebutuhan terutama dalam modal kerja (Sawir, 2005), dan memaksimalkan kinerja dengan tepat. Perusahaan yang memiliki Current Ratio (CR) yang besar menunjukkan kinerja yang tinggi dan tingkat pengembalian return yang tinggi (Borhan, 2014). Penelitian yang dilakukan oleh Ashraf (2017) menyimpulkan bahwa Current Ratio (CR) memiliki pengaruh positif terhadap pengembalian saham. Berdasarkan penjelasan diatas maka hipotesis yang didapat sebagai berikut:

$\mathrm{H}_{3}$ : Current Ratio (CR) berpengaruh positif terhadap return saham

(Habbe. Et al, 2001) melakukan pengujian mengenai korelasi antara price earning ratio terhadap return saham pada perusahaan go public di Bursa Efek Jakarta. Sampel penelitian menggunakan perusahaan go publik di Bursa Efek Jakarta (BEJ) tahun 1991 sampai 1995. Hasil penelitian menunjukkan bahwa Price earning ratio memiliki pengaruh 
terhadap return saham, price earning ratio dapat dikatakan sebagai komponen analisis rasio yang digunakan dalam mengambil keputusan investasi.

Nilai PER yang tinggi dapat mengurangi ketertarikan investor terhadap suatu saham. Hal ini disebabkan karena nilai PER memiliki indikasi bahwa harga suatu saham terlalu mahal, sehingga harga saham tersebut kemungkinan tidak akan naik lagi dan pada akhirnya peluang memperoleh return akan kecil. Penelitian yang dilakukan (Carpenter, 2020) menunjukan adanya hubungan negatif antara return saham dan PER.

PER dapat dijadikan sebagai bahan pertimbangan investor untuk melihat besar tidaknya return, setiap kenaikan PER mengindikasikan terjadinya penurunan return saham, dan penurunan PER mengindikasikan kenaikan return saham. Investor dapat membeli saham berkategorikan undervalued dan menjual saham overvalued untuk mendapatkan gain yang cukup besar (Chordia et al, 2011). Berdasarkan penjelasan diatas maka hipotesis yang digunakan adalah:

$\mathrm{H}_{4}$ : Price earning ratio (PER) berpengaruh negatif terhadap return saham

\section{Pengaruh Resiko sistematis terhadap return saham}

Pengukuran resiko dalam CAPM digunakan beta sebagai pengukur resiko. Investor yang efisien melakukan penanaman modal pada investasi yang memberikan resiko tertentu dengan tingkat keuntungan sama, tetapi mempunyai resiko yang berbeda, maka investor yang rasional akan memilih resiko yang lebih kecil. Semakin besar beta semakin besar pula tingkat keuntungan yang diharapkan dari investasi tersebut, karena beta dengan return memiliki arah yang positif (Girardi, 2013).

Penelitian terdahulu memiliki hasil yang berbeda mengenai pengaruh beta terhadap return saham, seperti yang dilakukan oleh Nasaer (2007) menyatakan bahwa beta berpengaruh positif dan signifikan terhadap return saham. Penelitian yang dilakukan oleh Solechan (2008) menghasilkan bahwa beta tidak memiliki pengaruh signifikan terhadap return saham. Berdasarkan penjelasan diatas penelitian ini menggunakan hipotesis sebagai berikut:

$\mathrm{H}_{5}$ : Resiko sistematis $(\beta)$ berpengaruh positif terhadap return saham

\section{METODOLOGI PENELITIAN}

Penelitian ini merupakan penelitian kuantitatif yang bertujuan untuk menguji hipotesis melalui validasi teori dan pengujian aplikasi teori (Apuke, 2017)

\section{Populasi dan Sampel}

Sampel yang digunakan dalam penelitian ini adalah perusahaan Konstruksi dan Infrastruktur yang terdaftar di Bursa Efek Indonesia untuk periode 2015-2019. Metode pengambilan sampel yang digunakan adalah purposive sampling. Klasifikasi data yang digunakan adalah perusahaan konstruksi dan infrastruktur yang memiliki total asset diatas 1 triliyun rupiah. Data penelitian ini diperoleh dari IDX Website www.idx.co.id. Hasil pengujian penelitian ini diolah dengan menggunakan Eviews 9.

\section{Variabel penelitian}

Variabel Dependen (Y)

Return saham (Y), adalah pengembalian yang diterima oleh pemodal atas investasi saham yang yang dilakukan (Kumar, 2015). Variabel return saham diukur dengan rumus sebagai berikut 


$$
\text { Return Saham }=\frac{\mathrm{Pt}-\mathrm{Pt}-1}{\mathrm{Pt}-1} \times 100 \%
$$

dimana :

Pt = Harga saham sekarang

Pt-1 = Harga saham periode sebelumnya

Variabel Independen (X)

Rasio Profitabilitas (X1)

Return On Assets (ROA) Menunjukkan kemampuan perusahaan dalam menghasilkan laba dengan memanfaatkan aktiva yang dimiliki (Khaddafi, 2014). Berikut perhitungan rumus :

Return On Asset $(\mathrm{ROA})=($ laba bersih setelah pajak $) /($ total aset $)$

Rasio Solvabilitas (X2)

Debt to Equity Ratio (DER) adalah tingkat penggunaan hutang terhadap total shareholder's equity yang dimiliki perusahaan. Rasio ini menunjukkan persentase penyediaan dana oleh pemegang saham terhadap pemberi pinjaman (Al-Malkawi et al, 2013). Dapat dihitung dengan rumus :

(Debt to Equity Ratio) DER=(total debt)/(total shareholder' s equity).

Rasio Likuiditas (X3)

Current Ratio (CR) yaitu rasio yang membandingkan jumlah aktiva lancar dengan hutang lancar untuk memperlihatkan seberapa besar ketersediaan aktiva lancar untuk menjamin hutang lancar (Borhan, 2014). Rumus CR sebagai berikut:

$\mathrm{CR}=($ Aktiva lancar $) /($ Kewajiban lancar $) \times 100$.

Rasio pasar (X4)

Menurut (Warrad, 2017) Price Earning Ratio (PER) merupakan perbandingan antara harga saham yang diperoleh dari pasar modal dengan laba per lembar saham yang diperoleh pemilik perusahaan. Berikut perhitungan rumus PER:

(Price Earning Ratio)PER=(harga saham)/(laba perlembar saham).

Beta saham (X5)

Beta saham merupakan pengukuran resiko yang berasal dari hubungan antara tingkat keuntungan suatu saham dengan pasar. Perubahan pasar dinyatakan sebagai akibat keuntungan indeks pasar (Xin Rui et al, 2018), maka tingkat keuntungan suatu saham dalam konsep model indeks tunggal dapat dinyatakan sebagai berikut. $\mathrm{R} 1=\alpha 0+\alpha 1 \mathrm{Rm}$

Keterangan: R1 : Tingkat keuntungan saham i.

$\alpha 0$ : Bagian dari tingkat keuntungan saham i yang tidak dipengaruhi oleh perubahan pasar.

$\alpha 1$ : Beta saham, merupakan parameter yang mengukur perubahan yang diharapkan pada $\mathrm{R} 1$ jika terjadi perubahan pada $\mathrm{Rm}$.

$\mathrm{Rm}$ : Tingkat keuntungan indeks pasar.

\section{Model Analisis Data}

Penelitian ini menggunakan model regresi data panel dibantu dengan software ekonometrika eviews 9, kemudian dilanjutkan dengan melakukan serangkaian pengujian yang meliputi uji pemilihan model menggunakan Uji Chow dan Uji Hausman. Pengujian yang kedua adalah uji $\mathrm{F}$ dan uji $\mathrm{T}$. Variabel terikat pada penelitian ini adalah Return 
saham (Y) dan variabel bebas dari penelitian ini adalah ROA (X1) DER(X2), CR(X3), PER(X4) dan BETA(X5). Secara umum didapat model persamaan $(\beta)$ sebagai berikut: $\mathrm{Y}=\beta 0+\beta 1 \mathrm{X} 1+\beta 2 \mathrm{X} 2+\beta 3 \mathrm{X} 3+\beta 4 \mathrm{X} 4+\beta 5 \mathrm{X} 5+\mathrm{e}$

Keterangan :

$\mathrm{Y}$

$\beta 0$

$\beta 1-\beta 5$

$\mathrm{X} 1$

$\mathrm{X} 2$

$\mathrm{X} 3$

$\mathrm{X} 4$

X5

e
$=$ Return Saham

$=$ Konstanta

= Koefisien Regresi Dari Setiap Variabel Independen

$$
=\text { ROA }
$$

$=$ DER

$=\mathrm{CR}$

$=$ PER

$=$ BETA

$=$ Standar kesalahan (error)

\section{Pemilihan Model Regresi Panel}

Data panel adalah gabungan diantara data cross section dan data time series. Terdapat beberapa pendekatan di dalam regresi panel, yaitu (1) pendekatan Common Effect; (2) Fixed Effects; dan (3) Random Effects. Dalam menentukan pilihan model terbaik, maka digunakanlah uji Chow test dan uji Hausman test. Uji Chow test dilakukan untuk membandingkan model terbaik antara common effect dan fixed effect. Uji hausman test dilakukan untuk membandingkan model terbaik antara fixed effect dan random effect (Bollan dan Brand, 2010).

Adapun prosedur pengujian dalam memilih model yang terbaik dalam regresi panel adalah sebagai berikut:

1. Uji Chow-test atau Likelihood Ratio-test

Pengujian dilakukan dengan menggunakan Chow-test dalam memilih model terbaik antara Common Effect dan Fixed Effect. Hipotesis yang digunakan sebagai berikut: $\mathrm{H}_{0}$ : Model mengikuti Common Effect Ha: Model mengikuti Fixed Effect. Ketentuan sebagai berikut jika probabilitas dari Cross-section Chi-square > 0,05 maka $\mathrm{H}_{0}$ diterima, namun jika probabilitas Cross- section Chi-square $<0,05$ maka $\mathrm{H}_{0}$ ditolak.

2. Uji Hausman test

Pengujian dilakukan dengan menggunakan Hausman test dalam memilih model terbaik antara Fixed Effect dan Random Effect. Hipotesis yang digunakan sebagai berikut: $\mathrm{H}_{0}$ : Model mengikuti Random Effect Ha: Model mengikuti Fixed Effect. Ketentuan sebagai berikut jika probabilitas Cross-section Random>0,05 maka $\mathrm{H}_{0}$ diterima, namun jika probabilitas Cross-section Random $<0,05$ maka $\mathrm{H}_{0}$ ditolak.

3. Uji Hipotesis

Uji kebenaran hipotesis yang telah ditetapkan kemudian diinterpretasikan hasilnya. Software Eviews 9 digunakan untuk memudahkan pengolahan data dengan melihat output yang dihasilkan antara lain:

a) Koefisien Determinasi

Koefisien determinasi (R2) digunakan untuk mengukur seberapa besar kemampuan model dalam menerangkan variasi dari variabel dependen. Nilai Koefisien determinasi (R2) yang Kecil menunjukan bahwa kemampuan variabel-variabel independen dalam menjelaskan variabel dependen sangatlah terbatas.

Nilai R2 dimulai dari angka 0 sampai dengan 1. Nilai yang mendekati satu berarti variabel-variabel independen memberikan hampir semua informasi yang dibutuhkan untuk memprediksi variabel independen. R2 memiliki kelemahan yang mendasar yaitu 
hasilnya bias terhadap variabel independen yang dimasukan ke dalam model. Setiap tambahan satu variabel independen akan menyebabkan nilai R2 meningkat.

b) Uji Statistik F

Uji statistik F digunakan untuk menguji secara simultan atau bersama-sama pengaruh dari variabel independen terhadap variabel dependen. Pengambilan keputusan berdasarkan hipotesis berikut: $\mathrm{H}_{0}$ : Variabel independen secara simultan atau bersama-sama tidak berpengaruh terhadap variabel dependen. $\mathrm{H}_{\mathrm{a}}$ : Variabel independen secara simultan atau bersama-sama berpengaruh terhadap variabel dependen. Adapun cara pengambilan keputusan uji statistik $F$ adalah sebagai berikut:

- Jika nilai signifikansi $<(\alpha 0,05)$ maka $\mathrm{H}_{0}$ ditolak

- Jika nilai signifikansi $>(\alpha 0,05)$ maka $\mathrm{H}_{0}$ diterima.

c) Uji t (Uji Parsial)

Uji statistik t digunakan untuk menguji koefisien regresi secara parsial atau individual, pengaruh variabel independen terhadap variabel dependen. Pengambilan keputusan berdasarkan hipotesis sebagai berikut: $\mathrm{H}_{0}$ : Masing-masing variabel independen secara parsial atau individual tidak berpengaruh terhadap variabel dependen. $\mathrm{H}_{\mathrm{a}}$ : Masing-masing variabel independen secara parsial atau individual berpengaruh terhadap variabel dependen. Adapun cara pengambilan keputusan uji statistik t adalah sebagai berikut:

- Jika nilai signifikansi $<(\alpha 0,05)$ maka $\mathrm{H}_{0}$ ditolak

- Jika nilai signifikansi $>(\alpha 0,05)$ maka $\mathrm{H}_{0}$ diterima.

\section{HASIL PENELITIAN}

Penelitian ini menggunakan uji regresi data panel untuk mengetahui pengaruh faktor fundamental dan resiko sistematis terhadap return saham pada perusahaan konstruksi dan Infrastruktur yang terdaftar di Bursa Efek Indonesia (BEI) pada tahun 2015-2019. Adapun hasil pengujian menggunakan bantuan software eviews 9 sebagai berikut:

1. Uji Pemilihan Model

a) Hasil Uji Chow

Uji Chow merupakan pengujian yang dilakukan untuk memilih apakah model yang digunakan Common Effect atau Fixed Effect. Hipotesis dari uji ini adalah:

$\mathrm{H}_{0}=$ Common Effect Model

$\mathrm{H}_{\mathrm{a}}=$ Fixed Effect

Tabel.1 Hasil Uji Chow

Redundant Fixed Effects Tests

Equation: Untitled

Test cross-section fixed effects

\begin{tabular}{cccc}
\hline \hline Effects Test & Statistic & d.f. & Prob. \\
\hline \hline Cross-section F & 1.798327 & $(8,31)$ & 0.0000 \\
Cross-section Chi-square & 17.155349 & 8 & 0.0000
\end{tabular}

Sumber: data diolah

Dari hasil regresi tabel di atas, didapatkan nilai probabilitas untuk Cross-section F sebesar 0.0000 dengan nilai $<0,05$. Maka $\mathrm{H}_{0}$ di tolak dan $\mathrm{H}_{\mathrm{a}}$ di terima, artinya dapat disimpulkan bahwa model Fixed Effect lebih baik dibandingkan dengan model Common Effect 
b) Hasil Uji Hausman

Uji Hausman Merupakan pengujian statistik yang dilakukan untuk memilih apakah model yang digunakan Fixed Effect Model atau Random Effect Model. Hipotesis sebagai berikut:

$$
\begin{aligned}
& \mathrm{H}_{0}=\text { Random Effect Model (REM) } \\
& \mathrm{H}_{\mathrm{a}}=\text { Fixed Effect Model (FEM) }
\end{aligned}
$$

Tabel.2 Hasil Uji Hausman

Correlated Random Effects - Hausman Test

Equation: Untitled

Test cross-section random effects

\begin{tabular}{cccc}
\hline \hline Test Summary & $\begin{array}{c}\text { Chi-Sq. } \\
\text { Statistic }\end{array}$ & Chi-Sq. d.f. & Prob. \\
\hline \hline Cross-section random & 10.677073 & 5 & 0.0082 \\
\hline \hline
\end{tabular}

\section{Sumber : data diolah}

Berdasarkan hasil estimasi Uji Hausman dalam menentukan Fixed Effect Model atau Random effect Model, di peroleh nilai probabilitas P Value (Prob>Chi2) $0.0082<$ Alpha 0,05 maka $\mathrm{H}_{0}$ di tolak dan $\mathrm{H}_{\mathrm{a}}$ di terima. sehingga dapat disimpulkan bahwa penggunaan pilihan model yang terbaik adalah Fixed Effect.

Uji pemilihan model di atas didapatkan hasil bahwa dari uji chow test terpilih model Fixed Effect daripada Common Effect, dan dari uji hausman test terpilih model fixed effect daripada random effect, sehingga model terbaik yang digunakan dalam penelitian ini adalah model fixed effect

\section{Pengujian Hipotesis}

Tabel.3 Hasil Estimasi Fixed Effec Model

\begin{tabular}{crrrr} 
Variable & Coefficient & Std. Error & t-Statistic & Prob. \\
\hline \hline C & 61.76255 & 32.54387 & 1.897824 & 0.0671 \\
X1 & 4.199001 & 2.974139 & 1.411838 & 0.0080 \\
X2 & -4.058179 & 4.636347 & -0.875297 & 0.0881 \\
X3 & -0.092066 & 0.154898 & -0.594365 & 0.5566 \\
X4 & -0.906999 & 0.392688 & -2.309718 & 0.0277 \\
X5 & 6.720964 & 9.285840 & -0.723786 & 0.0046 \\
\hline \hline
\end{tabular}

Cross-section fixed (dummy variables)

\begin{tabular}{lrll}
\hline \hline R-squared & 0.524667 & Mean dependent var & 29.92644 \\
Adjusted R-squared & 0.325334 & S.D. dependent var & 21.62045 \\
S.E. of regression & 17.75861 & Akaike info criterion & 8.841165 \\
Sum squared resid & 9776.419 & Schwarz criterion & 9.403238 \\
Log likelihood & -184.9262 & Hannan-Quinn criter. & 9.050700 \\
F-statistic & 2.632115 & Durbin-Watson stat & 2.430362
\end{tabular}


Sumber : data diolah

Berdasarkan hasil Uji Chow, dan Uji Hausman pada tabel diatas terpilih model yang terbaik yaitu model Fixed Effect sebagai model estimasi untuk mengetahui pengaruh variabel independen terhadap variabel dependen. Dari hasil persamaan tersebut, maka dapat diinterpretasikan secara ekonomi sebagai berikut:

- Uji Simultan (Uji F)

Estimasi yang digunakan dalam penelitian ini menggunakan regresi data panel dengan pendekatan terpilih adalah fixed effect model. Pada penelitian ini menggunakan nilai signifikansi $\alpha$ sebesar 5\% $(0,05)$.

Hasil pengujian statistik secara simultan dapat diketahui bahwa nilai probabilitas F sebesar 0.01 lebih kecil dari tingkat signifikansi alpha 5\%. Kesimpulan adalah hipotesis nol ditolak dan menerima hipotesis alternatif. Variabel ROA, DER, CR, PER, dan BETA secara signifikan bersama-sama mempengaruhi Return saham pada tingkat kepercayaan $95 \%(\alpha=0,05)$.

b) Uji Signifikansi Parameter Individual (Uji T)

Uji T digunakan untuk menguji pengaruh variabel independen secara individual terhadap variabel dependen. Derajat kepercayaan yang digunakan untuk penelitian ini sebesar 95\% $(\alpha=0,05)$. Apabila nilai signifikansi $<0,05$ maka $\mathrm{H}_{\mathrm{a}}$ diterima. Hal ini menandakan bahwa variabel independen secara parsial/individu dapat berpengaruh terhadap variabel dependen. Dapat dijelaskan sebagai berikut:

1) Pengaruh Rasio Profitabilitas (ROA) terhadap Return saham

Nilai koefisien dari variabel ROA (X1) sebesar 4.199001 dengan probabilitas 0.0080. Hasil ini menunjukkan bahwa variabel ROA memiliki hubungan positif dan signifikan terhadap variabel Return saham, yaitu ketika terjadi penambahan nilai ROA sebesar 1 persen secara otomatis nilai Return saham akan bertambah sebesar 4.1. Hasil penelitian ini sesuai dengan hipotesis penelitian Witkowska (2004), dan Ulupui (2005), bahwa pertumbuhan aset menyebabkan terjadinya peningkatan laba bersih, jika laba bersih naik maka asset perusahaan akan meningkat, dan hal ini berdampak terhadap kebijakan return saham berupa dividen yang ikut naik.

2) Pengaruh rasio Solvabilitas (DER) terhadap return saham

Nilai koefisien dari variabel DER (X2) sebesar -4.058179 dengan probabilitas 0.0881. Hal ini menunjukkan bahwa variabel DER memiliki hubungan negatif dan tidak signifikan terhadap variabel Return saham. Temuan analisis sesuai dengan hipotesis penelitian (Al-Malkawi et al, 2013).

Peningkatan leverage yang terlalu tinggi akan menyebabkan utang perusahaan menjadi meningkat, sehingga jika tidak di kelola dengan prinsip yang baik (Corporate governance) dapat menyebabkan kendala finansial, maka akan memicu financial distress pada perusahaan. (Cheng, 2011).

3) Pengaruh rasio Likuiditas (CR) terhadap return saham

Nilai koefisien dari variabel Current Ratio (X3) sebesar -0.092066 dengan probabilitas 0.5566 . Hal ini menunjukkan bahwa variabel CR memiliki hubungan negatif dan tidak signifikan terhadap variabel return saham. Kondisi ini mengandung arti bahwa Current Ratio yang rendah dianggap menunjukkan terjadinya masalah dalam likuiditas dan merupakan indikator awal mengenai ketidakmampuan perusahaan untuk memenuhi kewajiban jangka pendek (Van Horne dan Wachowics, 2009). 
Current Ratio yang tinggi memiliki arti likuiditas yang tinggi, namun kondisi tersebut menunjukkan bahwa perusahaan kurang mampu mengelola money to create money, yang pada akhirnya dapat mengurangi kemampuan perusahaan dalam memaksimalkan pendapatan. Temuan ini tidak sesuai dengan teori dan hipotesis penelitian yang menyatakan bahwa peningkatan likuiditas memiliki pengaruh positif dan signifikan terhadap return saham (Ashraf, 2017).

4) Pengaruh Rasio pasar (PER) terhadap return saham

Nilai koefisien dari variabel PER (X4) sebesar -0.906999 dengan probabilitas 0.0277. Hal ini menunjukkan bahwa variabel PER memiliki hubungan signifikan terhadap variabel Return saham. Price Earning Ratio yang rendah dapat berarti bahwa saham perusahaan tersebut memiliki harga pasar yang lebih rendah dibandingkan nilai intrinsiknya (undervalued). Investor menjadi tertarik untuk berinvestasi di dalam perusahaan tersebut (Carpenter, 2020).

Investor cenderung memilih perusahaan dengan nilai PER yang rendah karena menganggap nilai PER yang tinggi menunjukkan harga saham yang mahal dan tidak sesuai dengan nilai intrinsiknya (overvalued), sehingga investor akan lebih berhati-hati dalam menanamkan modal di perusahaan tersebut. Hasil penelitian ini sesuai dengan teori dan hipotesis yang menyatakan bahwa PER memiliki pengaruh negatif dan signifikan terhadap return saham (Qadir, 2011).

5) Pengaruh Resiko sistematis (BETA) terhadap return saham

Nilai koefisien dari variabel BETA (X5) sebesar 6.720964 dengan probabilitas 0.0046. Hal ini menunjukkan bahwa variabel BETA memiliki hubungan signifikan terhadap variabel Return saham.

Hasil ini sejalan dengan penelitian yang dilakukan oleh Alfred (2005) yang menyatakan bahwa secara parsial resiko sistematis berpengaruh positif dan signifikan terhadap return saham. Menurut Sharpe, Lintner, dan Mossin dalam Chang (2011) model CAPM menyatakan bahwa hubungan beta dengan return saham memiliki hubungan yang positif yaitu semakin besar risiko maka semakin besar pula return yang diperoleh dari koefisien beta.

c) Koefisien Determinasi (R2)

Koefisien determinasi (R2) digunakan untuk mengukur sejauh mana kemampuan variabel independen secara simultan dalam menjelaskan variabel dependen. Berdasarkan tabel diatas, di ketahui nilai koefisien determinasi (R2) sebesar 0.524667. artinya variabel independen (ROA, DER, CR, PER, dan BETA) mampu menejelaskan variabel dependen (Return saham) sebesar 52.4\% sedangkan sisanya di jelaskan variabel lain diluar model penelitian.

\section{KESIMPULAN}

Penelitian ini memiliki tujuan untuk menganalisis pengaruh faktor Fundamental dan Resiko sistematis perusahaan Konstruksi dan Infrastruktur yang berada di bursa efek indonesia terhadap return saham pada tahun 2015-2019. Hasil dari penelitian dapat disimpulkan bahwa secara simultan faktor fundamental yaitu Rasio Profitabilitas (ROA), Rasio solvabilitas (DER), Rasio Likuiditas (CR), Rasio pasar (PER), dan Resiko sistematis (BETA) berpengaruh signifikan terhadap return saham, dan secara parsial variabel Rasio Profitabilitas (ROA), Rasio pasar (PER), dan Resiko sistematis (BETA) berpengaruh secara signifikan terhadap return saham. Variabel Rasio Solvabilitas (DER) dan Rasio Likuiditas (CR) tidak memiliki pengaruh signifikan terhadap return saham. 


\section{DAFTAR PUSTAKA}

Anwaar, M. (2016). Impact of Firms Performance on Stock Returns (Evidence from Listed Companies of FTSE-100 Index London, UK). Global Journal of Management and Business Research: Accounting and Auditing, 16(1), 19-31. Retrieved from https://journalofbusiness.org/index.php/GJMBR/article/view/1961

Abarbanell, J. S. \& Bushee, B. J. (1998). Abnormal Returns to A Fundamental Analysis Strategy. The Accounting Review, 73(1), 19-45.

Acheampong, P., Agalega, E., \& Shibu, A. K. (2014). The effect of financial leverage and market size on stock returns on the Ghana Stock Exchange: evidence from selected stocks in the manufacturing sector. International Journal of Financial Research, 5(1), 125.

Berry-Stölzle, T. R., Kläver, H., \& Qiu, S. (2011). How does the liability structure affect incentives to invest in hedge funds? The case of with-profit life insurance. Journal of Insurance Issues, 34-67.

Bollen, K. A., \& Brand, J. E. (2010). A general panel model with random and fixed effects: A structural equations approach. Social Forces, 89(1), 1-34.

Beneish, M. D., Lee, C. M., \& Tarpley, R. L. (2001). Contextual fundamental analysis through the prediction of extreme returns. Review of Accounting Studies, 6(2-3), 165-189.

Čaljkušić, V. (2011). Fundamental and technical analysis on Croatian stock market. Croatian Operational Research Review, 2(1), 71-80.

Campbell, J. Y., Polk, C., \& Vuolteenaho, T. (2010). Growth or glamour? Fundamentals and systematic risk in stock returns. The Review of Financial Studies, 23(1), 305344.

Carpenter, J. N., Lu, F., \& Whitelaw, R. F. (2020). The real value of China's stock market. Journal of Financial Economics.

Chordia, T., Roll, R., \& Subrahmanyam, A. (2011). Recent trends in trading activity and market quality. Journal of Financial Economics, 101(2), 243-263.

Eric, G. \& Omran, M. (2009). On The Relationship Between Trading Volume And Stock Price Volatility In CASE, 2, 110-134. Retrieved from https://www.researchgate.net/publication/46545462_On_the_relationship_betwee n_trading_volume_and_stock_price_volatility_in_case.

Girardi, G., \& Ergün, A. T. (2013). Systemic risk measurement: Multivariate GARCH estimation of CoVaR. Journal of Banking \& Finance, 37(8), 3169-3180.

Goodman, T., Neamtiu, M., \& Zhang, X. F. (2018). Fundamental analysis and option returns. Journal of Accounting, Auditing \& Finance, 33(1), 72-97.

Hasintongan \& Rudy, R. (2010). Analysis of The Influence of Accounting Variables on Stock Returns, Bachelor Thesis. Faculty of Economics and Business. University of Amsterdam.

Hooi, S. E., Albaity, M., \& Ibrahimy, A. I. (2015). Dividend policy and share price volatility. Investment Management and Financial Innovations, 12(1), 226-234. 
Jones, C. M., Kaul, G., \& Lipson, M. L. (1994). Transactions, volume, and volatility. The Review of Financial Studies, 7(4), 631-651.

Kamar, K. (2017). Analysis of the effect of return on equity (ROE) and debt to equity ratio (DER) on stock price on cement industry listed in Indonesia stock exchange (IDX) in the year of 2011-2015. IOSR Journal of Business and Management, 19(05), 66-76.

Komala, L. A. P., \& Nugroho, P. I. (2013). The effects of profitability ratio, liquidity, and debt towards investment return. Journal of Business and Economics, 4(11), 11761186.

Li, T. C., Yuan, C. S., Huang, H. C., Lee, C. L., Wu, S. P., \& Tong, C. (2017). Clustered long-range transport routes and potential sources of PM2. 5 and their chemical characteristics around the Taiwan Strait. Atmospheric Environment, 148, 152-166.

Li, K., Griffin, D., Yue, H., \& Zhao, L. (2013). How does culture influence corporate risk-taking?. Journal of Corporate Finance, 23, 1-22.

Mustofia, M., Puspitaningtyas, Z., \& Sisbintari, I. (2019). Pengaruh Profitabilitas dan Investment Opportunity Set terhadap Kebijakan Dividen.

Muhadiyah, A., \& Amperaningrum, I. (2017). Analisis Fundamental Dan Pengaruhnya Terhadap Return Saham Perusahaan Indeks Lq-45 Yang Terdaftar Di Bursa Efek Indonesia Periode Tahun 2011-2014. Jurnal Ilmiah Ekonomi Bisnis, 22(1).

Muhammad, N., \& Scrimgeour, F. (2014). Stock returns and fundamentals in the Australian market. Asian Journal of Finance \& Accounting, 6(1), 271-290.

Marinda, N. M. (2017). Faktor Fundamental dan Volatilitas Harga Saham dengan Pemediasi Kebijakan Deviden-Kasus Perusahaan Properti dan Real Estate di Indonesia. Reseacrh Gate See discussions, stats, and author profiles for this publication.

Polakitan, C. D. (2015). Analisis komparasi risiko saham LQ 45 dan non LQ 45 pada beberapa sub sektor perusahaan yang terdaftar di bursa efek indonesia (BEI). Jurnal Riset Bisnis dan Manajemen, 3(1).

Rapach, D., \& Zhou, G. (2013). Forecasting stock returns. In Handbook of economic forecasting (Vol. 2, pp. 328-383). Elsevier.

Thampanya, N., Wu, J., Nasir, M. A., \& Liu, J. (2020). Fundamental and behavioural determinants of stock return volatility in ASEAN-5 countries. Journal of International Financial Markets, Institutions and Money, 65, 101193.

Walkshäusl, C. (2013). The high returns to low volatility stocks are actually a premium on high quality firms. Review of Financial Economics, 22(4), 180-186. 